\title{
Evaluation of the effects of grass species, irrigation, nitrogen fertiliser application and soil compaction on the response of modern dairy pastures to phosphorus fertiliser
}

\author{
A.D. MACKAY ${ }^{1}$, A. GILLINGHAM ${ }^{2}$, C. SMITH $^{3}$, P. BUDDING ${ }^{1}$, \\ P. PHILLIPS ${ }^{4}$, W. CLARKE-HILL ${ }^{5}$ and P. JOHNSTONE ${ }^{6}$ \\ ${ }^{1}$ AgResearch Grasslands, Private Bag 11008, Palmerston North \\ 242 Waicola Drive, Aokautere \\ ${ }^{3}$ AgResearch, Woodlands Research Station, RD 1, Invercargill \\ ${ }^{4} \mathrm{AgResearch}$, Ruakura Research Centre, Private Bag 3123, Hamilton \\ ${ }^{5}$ AgResearch, Lincoln Research Centre, Private Bag 4749 Christchurch \\ ${ }^{6}$ AgResearch, Invermay Research Centre, Private Bag 50034, Invermay \\ alec.mackay@agresearch.co.nz
}

\begin{abstract}
This paper summarises progress in a field-based study exploring the phosphorus $(\mathrm{P})$ requirements of high producing perennial ryegrass (Lolium perenne) and tall fescue (Festuca arundinacea)-based pastures, where the constraints to pasture growth and associated $\mathrm{P}$ uptake imposed by low nitrogen $(\mathrm{N})$ availability and soil moisture over summer-autumn and poor physical condition of the soil have been removed. Field sites are located in the Waikato, Manawatu, Canterbury and Southland. Initial findings indicate that the critical Olsen $\mathrm{P}$ level for near maximum (97\%) pasture production is greater than current industry standard. A higher Olsen P appears to compensate to some degree for the negative impact of a compacted soil on pasture growth. The implications of the present findings to current soil test interpretation and recommendations are discussed.
\end{abstract}

Keywords: phosphorus, pasture growth, Olsen P, soil compaction

\section{Introduction}

The current industry standard for the critical soil Olsen $\mathrm{P}$ for $97 \%$ of maximum pasture production are 20 and $22 \mu \mathrm{gP} / \mathrm{ml}$ for a sedimentary and volcanic ash soil, respectively (Roberts \& Morton 2009). Because of the variability in the calibration curves between Olsen $\mathrm{P}$ and relative pasture production, and also in soil test results, Roberts \& Morton (2009) point out there is no precise soil P level that will guarantee a particular level of pasture production (Fig. 1). The reason for the wide scatter of relative yield (RY) points associated with any Olsen P value (Fig. 1) can be related to variability in the effects of unrecorded 'other factors', such as moisture and $\mathrm{N}$ availability, affecting pasture growth. The adoption of a range in Olsen $\mathrm{P}$ as a guideline for fertiliser recommendations is recognition of the effects of these unrecorded 'other factors' on pasture productivity on each farm.
Roberts \& Morton (2009) recommend that to reduce the risk of under-fertilising pastures for sites that may fall below the average curve (Fig. 1), two target ranges should be added, with the range based on production of milksolids/ha. For both sedimentary and volcanic ash soils the target Olsen P range is $20-30 \mu \mathrm{gP} / \mathrm{ml}$ where milksolids production/ha is near the average for the local supply area, and $30-40 \mu \mathrm{gP} / \mathrm{ml}$ if production is in the top $25 \%$ for the local supply area (Roberts \& Morton 2009). At the other extreme, when comparing results from $0-20$ and 30-40 degree slopes in Waikato hill pasture, Gillingham et al. (1984) found that near maximum pasture production from summer-dry steep slopes was at an Olsen $\mathrm{P}$ of $10 \mu \mathrm{gP} / \mathrm{ml}$, whereas maximum production from gentle slopes was twofold higher with an Olsen $\mathrm{P}$ of $15 \mu \mathrm{gP} / \mathrm{ml}$. This finding suggests that as the constraints to the expression of pasture response to added $\mathrm{P}$ decreased the critical Olsen $P$ value increased.

In a review of the soil $\mathrm{P}$ database on which the calibration curves of Roberts \& Morton (2009) were based, Edmeades et al. (2006) derived higher critical Olsen P levels for 97\% maximum pasture production for all soil groups. The most likely reason for this finding was the application of a more rigorous protocol in the selection of the $\mathrm{P}$ field trial results for inclusion in the analysis. Over $70 \%$ of the large data base of P field trials on which the production function between Olsen $\mathrm{P}$ and RY for the major soil groups was based, came from permanent pastures producing $<10000 \mathrm{~kg} \mathrm{DM} /$ ha/yr. Little fertiliser $\mathrm{N}$ was applied in these studies and few were irrigated.

This situation has changed in the last two decades with a greater emphasis on pasture renewal with new germplasm, increasing use of $\mathrm{N}$ fertiliser and increasing hectares under irrigation. The overall nutrient status of dairy pasture soils has also increased (Wheeler 2004). This raises the question as to how representative are 
Figure 1 The relationship between relative pasture production (80-99\%) and Olsen P (10-40) for ash soils (adapted from Roberts \& Morton (2009)).

\section{Ash soils}

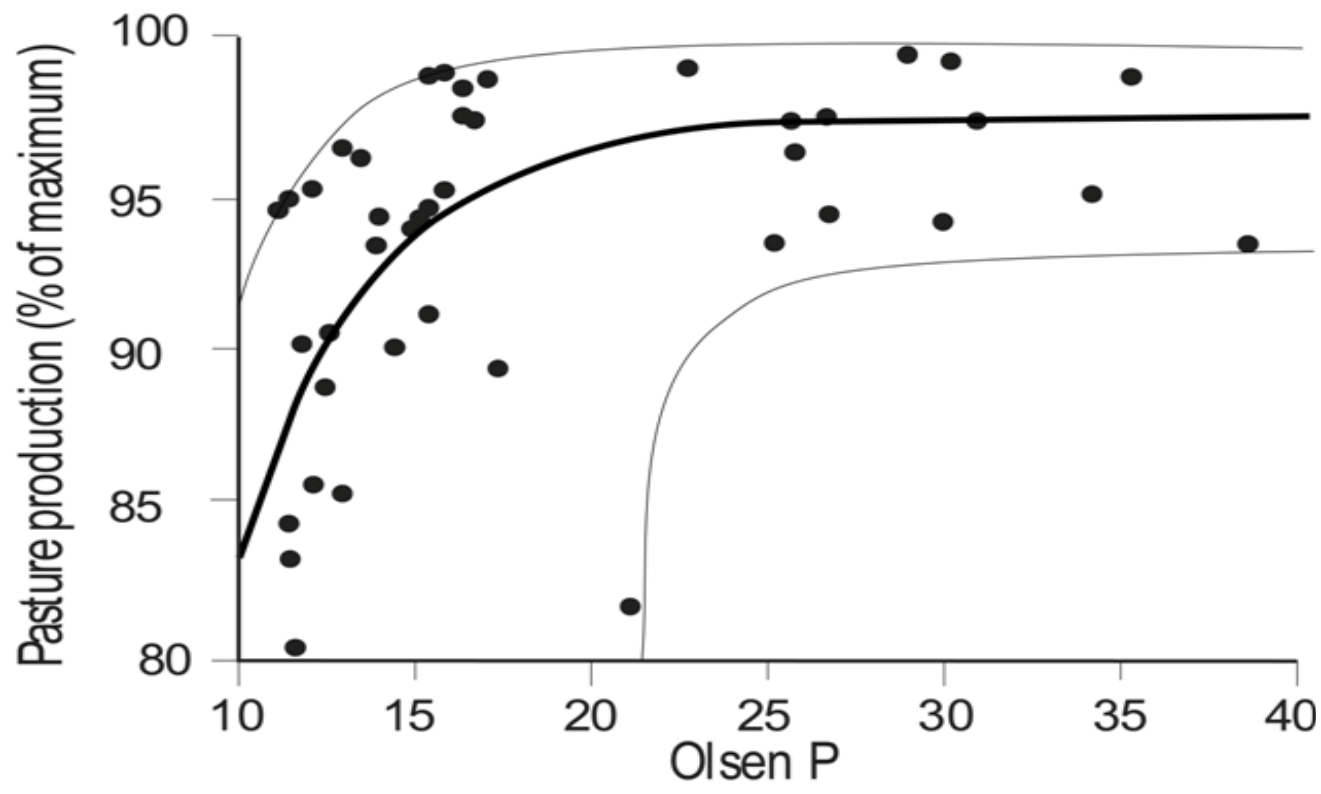

the currently recommended critical Olsen $\mathrm{P}$ values for today's pastures when the constraints to growth have been progressively removed.

This paper summarises progress of a field-based study exploring the $\mathrm{P}$ requirements of high producing pastures, where the pasture growth constraints imposed by low $\mathrm{N}$ availability and low soil moisture over summer-autumn have been removed. The field-based programme also extends to include an evaluation of the effects of soil compaction on pasture response to a range of Olsen $\mathrm{P}$ levels. Soil compaction is an emerging challenge facing the livestock industry. For example, a survey of soil quality in New Zealand by Sparling \& Schipper (2004) found low macroporosity arising from moderate compaction in many pasture soils, with half the dairy sites, predominantly on the more resilient soils having a macroporosity of $<10 \%$. The loss of macropores impacts on pasture growth through reduced soil aeration and drainage and increased gaseous losses of N. Drewry et al. (2002) found spring pasture growth improved by $1.5 \%$ per unit of macroporosity between a macroporosity of $5-15 \%$.

\section{Materials and Methods}

Field locations and experimental design of $P$ response study

There are three field sites in the Waikato, one under irrigation established in 2005, and one rain-fed and one irrigated established in 2008. In the Manawatu there are two trial sites; one under irrigation established in 2005, and another rain-fed established in 2007. Canterbury has one irrigated site established in 2008, and there is one irrigated field site in Southland established in 2005. In 2009-2010 the site established in 2008 in the Waikato was not irrigated. In Canterbury irrigation was suspended in March 2010. Except for the two Waikato sites where tall fescue ('Advance' MaxP) was sown, all other sites were sown with a perennial ryegrass 12 months before establishing the $P$ response study. A range of ryegrass cultivars were used including 'Bronsyn' and 'Impact' with AR1 endophyte in Waikato, 'Bronsyn' and 'Meridian' with Standard endophyte (SE) in Manawatu and 'Impact' and 'Sterling' with no endophyte in Southland. Modern white clover (Trifolium repens) cultivars were sown at all sites and included 'Aran' and 'Kopu' in the Waikato, 'Sustain' and 'Kopu' in the Manawatu and 'Demand' and 'Sustain' in Southland. At the three Waikato sites soils are derived from volcanic material. At the other sites soils are derived from sedimentary material.

Field trial design was the same at all sites; $5 \mathrm{P} \times 2$ $\mathrm{N}$ treatment factorial with 4 replicates. Five Olsen $\mathrm{P}$ levels of $10-15,20-25,30-35,40-45$ and $>60 \mu \mathrm{gP} / \mathrm{ml}$ were generated by appropriate capital $\mathrm{P}$ inputs of triple super in split applications at the start of each study. Two rates of $\mathrm{N}$ fertiliser 0 and $400 \mathrm{~kg} \mathrm{~N} / \mathrm{ha} / \mathrm{yr}$ as urea 
were applied in applications of $40 \mathrm{~kg} \mathrm{~N} / \mathrm{ha}$ at about monthly intervals, following each pasture measurement from August to June. Further applications of $\mathrm{P}$ were made annually to adjust and maintain the target Olsen P levels. Basal applications of $200 \mathrm{~g} / \mathrm{ha}$ Mo as sodium molybdate was applied at the trial start and $30 \mathrm{~kg} / \mathrm{ha}$ calcined magnesite, $10 \mathrm{~kg} / \mathrm{ha}$ zinc sulphate, $10 \mathrm{~kg} / \mathrm{ha}$ copper sulphate and $11.25 \mathrm{~kg} / \mathrm{ha}$ sodium tetraborate each year. Potassium chloride fertiliser $(50 \mathrm{~kg} \mathrm{~K} / \mathrm{ha})$ was applied 4 times per year, with $\mathrm{S}$ fertiliser consisting of a mix of Gypsum and elemental S applied at a rate of 50 $\mathrm{kg} \mathrm{S} / \mathrm{ha}$ every 6 months. Trials were fenced to exclude livestock and trimmed to leave a residue of 1400-1 800 $\mathrm{kg} \mathrm{DM} /$ ha following each measurement. All clippings were removed. Pasture production was measured using a rising plate meter at about monthly intervals, with a standard calibration curve used to convert height measurements to DM yield. Calibrations were checked against cuts at some sites. Soil samples were collected from each plot $(0-75 \mathrm{~mm})$ before the start of the trials and in late November-early December each year.

\section{Field locations and experimental design of soil} compaction study

There are two soil compaction studies, one in Manawatu and one in Southland. Both sites were sown with modern ryegrass cultivars including 'Bronsyn' and 'Meridian' with SE in Manawatu and 'Impact' and 'Sterling' with no endophyte in Southland, before the start of the studies in 2007 and 2008, respectively. Soils were derived from sedimentary material. Field trial design at both sites was a split plot, with four P treatments within each of three compaction levels (Southland) and four compaction levels (Manawatu), with four replicates at each site. The soil compaction treatments, imposed using a heavy roller, commenced in Manawatu and Southland in 2007 and 2008, respectively, and are repeated at intervals during spring-summer. The roller can only compact the surface soil without any deformation as often occurs with the hooves of grazing cows, so differences in pasture production can only be associated with soil compaction effects. Olsen $\mathrm{P}$ levels of $10-15,20-25,30-40$, and $>60 \mu \mathrm{gP} / \mathrm{ml}$ were generated by appropriate capital $\mathrm{P}$ inputs of triple super applied in split applications at the start of each study. Further applications of $\mathrm{P}$ are made annually to adjust and maintain the target Olsen P levels. Management of the trial at each site followed the protocols described above. Soil cores are taken each spring to measure bulk density and pore size distribution.

\section{Analysis}

All data (P response, Olsen $\mathrm{P}$ x soil compaction) were analysed to determine treatment effects using ANOVA
Figure 2 Relationship between relative yield and Olsen P for all sites where an asymptote could be established. $\mathrm{O}=$ Ryegrass pasture without added $\mathrm{N} ; \boldsymbol{\bullet}=$ Ryegrass pasture with added $\mathrm{N} ; \Delta=$ Tall fescue pasture without added $\mathrm{N} ; \boldsymbol{\Delta}=$ Tall fescue pasture with added $\mathrm{N}$.

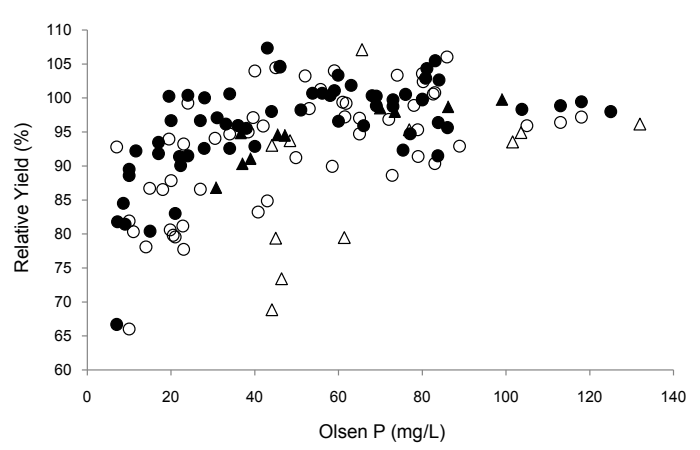

within Genstat (v 10). The P response curves for the two $\mathrm{N}$ treatments ( 0 and $400 \mathrm{~kg} \mathrm{~N} / \mathrm{ha}$ ) were compared via a SSPLINE function for the annual DM yield totals. To examine the $\mathrm{P}$ response curves from the analysed yield data, data for the individual $\mathrm{N}$ treatments of each year were first fitted by means of Mitscherlich response curves against the Olsen $\mathrm{P}$ from the November soil sample of that year. There were 34 data sets $(5$ sites $\mathrm{x}$ 1 - 5 years $x 2 \mathrm{~N}$ rates).

\section{Results and Discussion}

\section{Relationship between relative yield and Olsen $P$}

The annual pasture response to $\mathrm{P}$ and $\mathrm{N}$ has been in the order of $5-25 \%$ and $20-60 \%$, respectively, over the 5 years of data collection from the nine field trials. The relationship between relative pasture yield (RY) and Olsen $\mathrm{P}$ for annual data sets from all sites over all years (Fig. 2) was described by a Mitscherlich response curve (18 out of 34 data sets):

$\mathrm{RY}(\%)=99.606-32.47 \times 0.941^{\text {Olsen P }}$ All annual data $\mathrm{r}^{2}=0.521$

The bulk of annual yields across all sites and years fell within the range of 12000 to $20000 \mathrm{~kg} \mathrm{DM} / \mathrm{ha} / \mathrm{yr}$. Using equation (1) near maximum pasture production, defined as the relative yield at $97 \%$ of maximum production, was achieved at an Olsen P level of $41 \mu \mathrm{gP} / \mathrm{ml}$.

The relationship between RY and Olsen $\mathrm{P}$ for annual production from all sites and years for each of the 0 $\mathrm{N}$ and $400 \mathrm{~N}$ application rates, were described by Mitscherlich response curves:

RY $(\%)=100.27-37.8 \times 0.944^{\text {Olsen P }}(6$ of 17 data sets) $\mathrm{r}^{2}=0.395,0 \mathrm{~N}$

RY $(\%)=99.04-33.74 \times 0.930^{\text {olsen P }}(12$ of 17 data sets) $r^{2}=0.611,400 \mathrm{~N}$

Near maximum pasture production $(97 \% \mathrm{RY})$ was achieved at an Olsen P level of $43 \mu \mathrm{gP} / \mathrm{ml}$ and $37 \mu \mathrm{gP} /$ 
$\mathrm{ml}$ for the $0 \mathrm{~N}$ and $400 \mathrm{~N}$ application rates, respectively, with the absolute pasture production significantly lower for the $0 \mathrm{~N}$ than $400 \mathrm{~N}$ treatment. The difference in critical Olsen $\mathrm{P}$ value was not significant, but importantly, a large number of the data sets for the relationship between relative yield and Olsen $\mathrm{P}$, where $0 \mathrm{~N}$ was applied, could be explained better by a linear function, indicating a critical Olsen $\mathrm{P}>43 \mu \mathrm{gP} / \mathrm{ml}$. The difficulty in defining the asymptote within acceptable tolerance levels (the standard error of the asymptote has to be $<10 \%$ of the asymptote) for $0 \mathrm{~N}$ might reflect the inability of the legume component of the sward to supply sufficient $\mathrm{N}$ for maximum pasture growth, due to factors limiting clover growth and $\mathrm{N}$ fixation (e.g. competition for moisture). Sinclair et al. (1997) noted that considerable error was involved in calculating relative yield, mostly due to the difficulty of predicting maximum actual yields. Moir et al. (2000), recognising this dilemma and the challenge created by climate variation, proposing a climate driven, soil fertility dependent pasture production model that predicts 'actual yields', as an alternative approach.

The current study indicates that the critical Olsen $\mathrm{P}$ level for a high producing pasture is higher than current industry standards. It is important to note that a different model- fitting approach was used to calculate the critical Olsen P value in the studies of Roberts \& Morton (2009) and Edmeades et al. (2006). This may explain in part the difference in the derived critical Olsen $P$ values.

It is interesting to compare the critical Olsen $P$ values found in the present study, with those of Gillingham et al. (1984) and Gillingham et al. (2007). Gillingham et al. (1984) found near maximum pasture production at a critical Olsen P level of $15 \mu \mathrm{gP} / \mathrm{ml}$ or less, and Gillingham et al. (2007) found near maximum pasture production at a critical Olsen P level closer to $20 \mu \mathrm{gP} /$ $\mathrm{ml}$ for sheep and beef pastures located on the East Coast of both Islands. Their field sites were characterised by old resident pastures, where frequent seasonal moisture deficits occurred. Pastures were grass-dominant and overall levels of production low, due to the combination of limited soil $\mathrm{N}$ availability from poor legume growth and moisture. This contrasts sharply with the characteristics of the field sites in the current study and suggests that as constraints are removed and production increases, so does the critical Olsen $\mathrm{P}$ value. It raises the question of the merit of continuing with a single relative response curve and critical Olsen $\mathrm{P}$ value for $97 \%$ of maximum production regardless of the absolute level of pasture production.

\section{Tall fescue response to $P$ and $\mathbf{N}$}

By December 2009, 2.5 years after sowing, the tall
Figure 3 Relationship between soil bulk density, Olsen $\mathrm{P}$ and pasture production ( $\mathrm{kg} \mathrm{DM} / \mathrm{ha}$ ) at the Southland site in $2009 / 2010$. LSD ${ }_{0.05}$ for comparing means with the same Olsen $P$ is 1154 and same soil bulk density is 1062 .

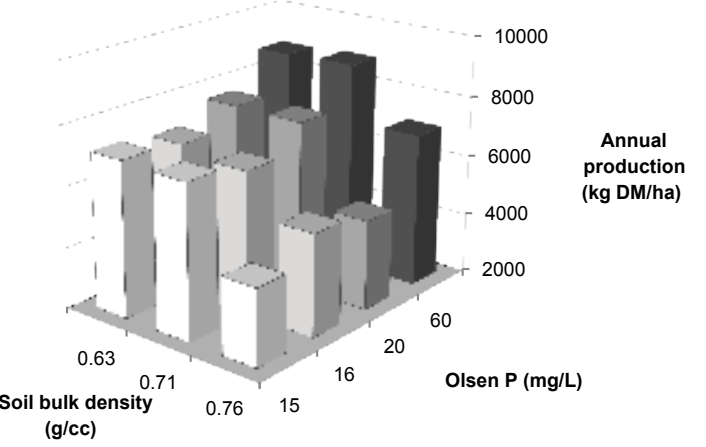

fescue-based pastures contained up to $90 \%$ of DM as tall fescue under the $\mathrm{N}$ treatment. These showed large responses to applied $\mathrm{N}$ and, production more than doubled (5 736 versus $13203 \mathrm{~kg} \mathrm{DM} / \mathrm{ha}$ ) in the second year. Legume growth has been poor in the tall fescue plots receiving no $\mathrm{N}$, with the white clover content limited to $<10 \%$ of DM in December 2009. A pasture response to increasing Olsen $\mathrm{P}(\mathrm{P}<0.001)$ was measured in the second year (2009/2010) with the Mitscherlich relationship between relative yield (RY) and Olsen $\mathrm{P}$ accounting for $85 \%$ of the variation in growth on the plots with added $\mathrm{N}$ :

RY $(\%)=99.34-78.2 \times 0.940$ Olsen P $\quad r^{2}=0.859$ (4)

When restricted to a few sites on the same soil it is not uncommon to find a good correlation between pasture production and Olsen $P$ (Edmeades et al. 2006). Near maximum pasture production was achieved at a much higher Olsen P using equation (4), than has been reported for ryegrass-based pastures. The literature suggests that the nutrient requirements of a tall fescue pasture are similar to other grass species (Miles \& Manson 1995). If tall fescue becomes more prominent in pasture mixes, a more detailed examination of its nutrient requirements would seem prudent based on these initial findings.

\section{Interaction between soil compaction, Olsen $P$ and pasture production}

At the Southland site a significant relationship between pasture yield and soil macroporosity was found in the spring of $2008\left(\mathrm{y}=580.3 \mathrm{x}-1198 \mathrm{r}^{2}=0.667\right), 6$ months after the compaction treatments were imposed. Both soil compaction $(\mathrm{P}<0.01)$ and Olsen $\mathrm{P}(\mathrm{P}<0.001)$ had an influence on pasture production in 2009-2010 (Fig. 3). Further, a significant interaction was found between soil compaction, Olsen $\mathrm{P}$ and autumn pasture production $(\mathrm{P}<0.05)$. However, this did not extend to annual 
pasture production at this site. A higher Olsen $\mathrm{P}$ appears to compensate to some degree for the negative impact of a compacted soil on pasture growth. Bulk density ranged from $0.63,0.71$ and $0.76 \mathrm{MgM}^{3}(\mathrm{P}<0.001)$ and macroporosity $14.5,10.5$ to $9.1 \%(\mathrm{P}<0.001)$ for the 0 , 1 and 2 compaction levels, respectively, in spring 2009.

At the Manawatu site the same trends appeared, but to date the negative influence of increasing soil compaction and positive influence of increasing Olsen $P$ have been limited to individual pasture cuts (data not shown). Soil bulk densities were $0.99,1.05,1.12$ and $1.15 \mathrm{MgM}^{3}$ and macroporosity 20.2, 16.0, 13.0 and 11.0 $\%$ for the $0,1,2$ and 3 compaction levels, respectively, in the spring 2008.

\section{Implications}

It would be easy to dismiss the findings of the relatively few data sets of the current study, which indicates that the critical Olsen $\mathrm{P}$ level for a high producing pasture is higher than the current industry standards, without an appreciation of the distribution of the pasture production levels in the P field trials data base used for current recommendations. This requires further investigation, including a comparison of the critical values of the current study with those reported by Roberts \& Morton (2009) and Edmeades et al. (2006) using a common modelling approach.

The results from this study do, however, support the contingency recommendation suggested by Roberts \& Morton (2009) to increase the soil Olsen P level in dairy farms that are operating at higher than average production levels. The recommended soil Olsen $\mathrm{P}$ level of $41 \mu \mathrm{gP} / \mathrm{ml}$ (equation (1)) for $97 \%$ of maximum production is similar to the upper end of the range suggested by Roberts \& Morton (2009).

Results to date from the current study are, however, inadequate to indicate whether grass-dominant pastures have a different $\mathrm{P}$ response curve to clover-based pastures. Pastures receiving high fertiliser $\mathrm{N}$ inputs, that become grass-dominant, may be expected to be more competitive in foraging for soil $\mathrm{P}$ than clover-based pasture (Jackman \& Mouat 1972) and therefore require a lower soil P level for optimum growth.

Factors most limiting pasture growth such as low soil moisture and $\mathrm{N}$ availability, could also be extended to include the low macroporosity of the surface soil. Initial findings suggest that the Olsen $\mathrm{P} x$ pasture RY function is modified by the physical condition of the soil. The negative impact of a compacted soil on pasture growth appears to be offset to some degree by lifting the Olsen P value. Inclusion of a measure of soil physical condition in either the derivation of relative $P$ response curves or in the interpretation of the Olsen $\mathrm{P}$ test value would appear to warrant further study, given the increasing cost of this nutrient, and the potential impact that soil with limited pore function and elevated Olsen $\mathrm{P}$ could have on surface water quality.

\section{ACKNOWLEDGEMENTS}

The authors wish to thank B \& C MacMillan of Crestview Farms Ltd. for access and use of a paddock on their farm, the provision of water for irrigation and for looking after the irrigator. We acknowledge the support of FRST/Pastoral sustainable forage productivity gains programme (C10X0604).

\section{REFERENCES}

Drewry, J.J.; Littlejohn, R.P.; Paton, R.J.; Singleton, P.L.; Boyes, M.; Judge, A.; Monaghan, R.M.; Smith, L.C. 2002. Dairy pasture yield responses to macroporosity and soil physical properties, and variability of large and small samples. pp. 61-78. In: Dairy farm soil management. Eds. Currie L.D.; Loganathan, P. Occasional Report No. 15, Fertilizer and Lime Research Centre, Massey University, Palmerston North, NZ.

Edmeades, D.C.; Metherell, A.K.; Waller, J.E.; Roberts, A.H.C.; Morton, J.D. 2006. Defining the relationships between pasture production and soil $\mathrm{P}$ and the development of a dynamic P model for New Zealand pastures: a review of recent developments. New Zealand Journal of Agricultural Research 49: 207-222.

Gillingham, A.G.; Richardson, S.C.; Riley, J. 1984. Rationalising topdressing of hill country. Proceedings of the New Zealand Grassland Association 45: 92-97.

Gillingham, A.G.; Morton, J.D.; Gray, M.H. 2007. Pasture responses to phosphorus and nitrogen fertilisers on East Coast hill country: total production from easy slopes. New Zealand Journal of Agricultural Research 50: 307-320.

Jackman, R.H.; Mouat, M.C.H. 1972. Competition between grass and clover for phosphate. 1. Effect of browntop (Agrostis tenuis Sibth) on white clover growth (Trifolium repens L.) New Zealand Journal of Agricultural Research 15: 653-666.

Miles, N.; Manson, A.D. 1995. Effects of soil acidity and phosphorus on the yield and chemical composition of tall fescue. Communications in Soil Science and Plant Analysis 26: 843-860.

Moir, J.L.; Scotter, D.R.; Hedley M.J.; Mackay, A.D. 2000. A climate driven, soil fertility dependent, pasture production model. New Zealand Journal of Agricultural Research 43: 491-500.

Roberts, A.H.C.; Morton, J.D. 2009. Fertiliser use on New Zealand dairy farms. New Zealand Fertiliser 
Manufacturers' Association, Auckland, New Zealand. http://www.fertresearch.org.nz/resourcecentre/booklets

Sinclair, A.G.; Johnstone, P.D.; Smith, L.C.; Roberts, A.H.C.; O'Connor, M.B.; Morton, J.D. 1997. Relationship between pasture dry matter yield and soil Olsen P from a series of long-term field trials. New Zealand Journal of Agricultural Research 40: 559-567.
Sparling, G.P.; Schipper, L.A. 2004. Soil quality monitoring in New Zealand: Trends and issues arising from a broad-scale survey. Agriculture Ecosystems and Environment 104: 545-552.

Wheeler, D.M. 2004. Trends in Olsen P test over time for the Waikato region: Waikato Regional Council. Environment Waikato. Technical Report TR 2004/09 $11 \mathrm{pp}$. 